\title{
O AXIOMA ENTRE A EXIGÊNCIA DE TRABALHO EXCESSIVO VERSUS O DIREITO AO LAZER DO TRABALHADOR: ANÁLISE SOB A ÓTICA DA RESPONSABILIZAÇÃO DO EMPREGADOR
}

Regina Célia Pezzuto Rufino

Advogada, Mestre em Direito do Trabalho pela PUC-SP e Doutora em Direito pela UMSA. Docente na disciplina de Direito do Trabalho, Processo e Direito Previdenciário na UNIP-SP, na Pós-Graduação Virtual da UNISUL-SC e na Pós-Graduação da UNIVEL-PR. Autora do Livro ASSÉDIO MORAL NO AMBITO DA EMPRESA - ed. LTr e do livro 0 PAPEL DAS UNIVERSIDADES FRENTE A VIOLENCIA DOS ALUNOS CONTRA O PROFESSOR: UMA VISÃO SOB A ÓTICA TRABALHISTA - ed. LTr, além de outros capítulos de livros e artigos jurídicos publicados no Brasil e no Exterior.

\section{Resumo}

As relaçóes trabalhistas focaram ao longo da história, os bens jurídicos materiais do trabalhador como contraprestaçáo dos serviços. Entretanto, paulatinamente, verificou-se a necessidade da valorização do trabalhador em sua essência humana, passando a vislumbrar a importância do respeito aos bens intrínsecos, sobretudo, aos direitos fundamentais. A presente pesquisa, elaborada pelo método dedutivo com embasamento doutrinário e jurisprudencial, justifica-se pela observação do abismo entre os ditames jurídicos e a experiência empírica dos trabalhadores no pleno exercício do lazer, tratando primeiramente da evolução do reconhecimento dos direitos fundamentais dos trabalhadores, passando para a temática das jornadas excessivas para o aumento de lucro do empregador e, posteriormente, abordará a responsabilidade deste último, quando o exacerbo de horas de trabalho subtrai o tempo destinado ao lazer dos trabalhadores. O Estado Democrático de Direito impóe o pleno exercício da cidadania através da liberdade de todos os direitos do indivíduo, sobretudo, os sociais, e o direito ao lazer passou a ser um bem garantido constitucionalmente. Contudo, a concorrência capitalista enseja a busca desenfreada de bens materiais decorrentes da alta produtividade oriunda de trabalho excessivo, o qual prejudica não somente a saúde e a vida do trabalhador, o priva da convivência com os entes queridos, sua inserção na sociedade e o pleno exercício do lazer, com autonomia de escolher como desfrutar seu tempo livre de forma digna, sem a preocupaçáo ou a imposição de produzir para sua subsistência. Desse modo, a jornada de trabalho excessiva afronta o direito fundamental ao lazer, não deixando espaço para a efetivação do mesmo, violando o exercício da cidadania do trabalhador, e ensejando na responsabilizaçáo do empregador no tocante ao ilícito que viola um direito de fundamental importância dos trabalhadores. 


\section{Palavras-chave}

Trabalhador; Jornada Excessiva; Lazer.

\section{Abstract}

Labor relations focused throughout history, legal worker material rights in exchange of services. However, gradually, there was the need for worker appreciation of his human essence, going to glimpse the importance of respecting the intrinsic goods, especially fundamental rights. This study, prepared by the deductive method with doctrinal and jurisprudential basis, justified by observing the gulf between the legal dictates and empirical experience of workers at full exercise of leisure, primarily dealing with the evolution of the recognition of the fundamental rights of workers, passing to the theme of excessive working hours to increase the employer's profit and subsequently address the responsibility of the latter, when exacerbated working hours subtracts the leisure time of workers. The democratic state imposes the full exercise of citizenship through freedom of every individual's rights, above all, the social and the right to leisure has become a well constitutionally guaranteed. However, capitalist competition entails the unbridled pursuit of material goods arising from high productivity coming from overwork, which not only harms the health and worker's life, deprived of living with loved ones, their integration into society and the full exercise of leisure, with autonomy to choose how to enjoy their free time in a dignified manner without the worry or the imposition of produce for their livelihood. Thus, the journey of excessive work affront the fundamental right to pleasure, leaving no room for the realization of the same in violation of the exercise of the worker's citizenship, and entailing the responsibility of the employer regarding the illicit violates a right of fundamental importance of workers.

\section{Key words}

Worker; Excessive Working Hours; Leisure.

\section{Introdução}

O presente trabalho analisa a responsabilidade do empregador perante a exigência de trabalho em jornada exaustiva de seus trabalhadores, estabelecendo uma comparação crítica entre os direitos sociais destes, sobretudo o direito ao lazer e a ânsia pelo aumento da produtividade e do lucro por parte do empregador, o que pode obstaculizar a função social e solidária da empresa

A análise desta problemática justifica-se pela observância da ineficácia prática de algumas premissas constitucionais impostas pelo Poder Público para o pleno exercício da 
cidadania, notadamente, da valorização dos direitos dos trabalhadores como atores integrantes da sociedade, abordando, através do método dedutivo o cenário e peculiaridades entre as relaçôes trabalhistas, normas tutelares e a imposição de respeito às condiçôes que favoreçam o efetivo cumprimento dos direitos sociais dos trabalhadores, para o satisfatório exercício da cidadania. Analisa ainda uma comparação crítica entre os ditames estabelecidos pelo legislador para garantia dos direitos sociais por parte do trabalhador e a realidade prática do cotidiano com entrave no excesso de jornada a que se submetem, na busca de um aumento na remuneração ou sob o receio da recusa de labor extraordinário e a perda do emprego.

$\mathrm{O}$ excesso de jornada visto de maneira tão corriqueira, nos dias atuais viola uma diversidade de direitos do trabalhador, sobretudo, a saúde, a vida e o lazer, sendo que este último, sequer é lembrado nas discussóes jurídicas, figurando como um bem social protegido pelo constituinte no plano da teoria, sem aplicação empírica, especialmente, nas relaçóes laborais.

Dessa forma impóe-se uma reflexão da importância deste bem jurídico protegido pelo constituinte em uma comparação com a ausência de tempo livre dos trabalhadores devido ao excesso de jornada, traçando uma vertente sob a ótica dos princípios, objetivos e premissas da República Federativa do Brasil, principalmente, a dignidade humana, com o objetivo de garantir a cidadania do trabalhador, culminando o respeito à democracia e a efetivação das diretrizes constitucionais e solidárias entre os atores das relações de trabalho.

\section{A Valorização do Trabalhador e o Respeito aos seus Direitos Fundamen- tais}

O trabalho humano, em qualquer modalidade, enaltece a dignidade do homem, sendo um bem indispensável para realização social e pessoal do ser, no entanto, a limitação do tempo despendido com o trabalho também faz-se necessária, a fim de observar o respeito aos demais direitos fundamentais do indivíduo.

\subsection{A Valorização dos Direitos Humanos do Trabalhador e as Premissas Consti- tucionais}

O homem sempre dependeu do trabalho para manter a sobrevivência. E, a necessidade de alimentar-se, bem como de proteger seu grupo social, ensejaram um aprimoramento do trabalho realizado, na busca da perpetuação da espécie. (BARROS, 2005)

A ocorrência da Revolução Industrial despertou a consciência de proteção do Estado em relação ao trabalhador, impossibilitado ou limitado para se defender diante da força 
econômica da indústria, decaindo a visão do poder absoluto do senhor feudal sobre seus servos, iniciando, assim, a valorização do trabalhador. (RUFINO, 2011)

A necessidade de surgimento de uma ordem jurídica que disciplinasse as questôes envolvendo o trabalhador e seus anseios e direitos se originou da questão social que foi precedida da Revoluçáo Industrial e da reaçáo humanista a que ela se propôs a garantir ou preservar a dignidade do ser humano ocupado no trabalho das indústrias. (NASCIMENTO, 2011)

A Declaração dos Direitos do Homem e do Cidadão, de agosto de 1789 marcou a valorização do homem, o que embasaria posteriormente, de forma mais consolidada a valorização do trabalhador. Esta Declaração, que se consubstanciou na Revolução Francesa, soou reflexos de extrema relevância para à valorização do homem. (RUFINO, 2011)

Contudo, a valorização do trabalhador, como de qualquer ser humano se consolidou com a Declaração Universal dos Direitos Humanos de 1948 que dispóe em seu art. 1º:

Considerando que o reconhecimento da dignidade inerente a todos os membros da família e de seus direitos iguais e inalienáveis é o fundamento da liberdade, da justiça e da paz no mundo.

art. $1^{\circ}$ - Todas as pessoas nascem livres e iguais em dignidade e direitos. São dotadas de razão e consciência e devem agir em relação uma às outras com espírito de fraternidade.

E em seu artigo 23:

1. Toda pessoa tem direito ao trabalho, à livre escolha de emprego, a condiçóes justas e favoráveis de trabalho e à proteção contra o desemprego.

2. Toda pessoa, sem qualquer distinção, tem direito a igual remuneração por igual trabalho.

3. Toda pessoa que trabalhe tem direito a uma remuneraçáo justa e satisfatória, que lhe assegure, assim como à sua família, uma existência compatível com a dignidade humana, e a que se acrescentaráo, se necessário, outros meios de proteçáo social.(g.n.)

4. Toda pessoa tem direito a organizar sindicatos e neles ingressar para proteção de seus interesses.

Desta forma, notório se perfaz que a partir da citada Declaração, a valorizaçáo do trabalhador se aliou a expressão de respeito às liberdades individuais, e exercício dos direitos sociais, exaltando a autonomia do indivíduo, considerando a pessoa humana um fim e não um meio, e com isto, exaltando o pleno exercício da cidadania. (RUFINO, 2011)

Com o advento da Constituição de 1988 que se caracterizou pelo retorno da democracia e da plena valorização do cidadão, em seus mais altos anseios, evoluiu a consciência 
da importância do exercício da cidadania, da valorização da dignidade como bem precípuo, e da preservação dos direitos fundamentais nas relaçóes interpessoais, sociais e no ambiente do trabalho. (RUFINO, 2011)

Verificou-se, portanto que os direitos humanos se correlaciona ao exercício da democracia, devendo ser respeitados em todos os aspectos, sobretudo, para preservação da liberdade, da autonomia dos bens intrínsecos ao ser humano, conforme preceitua Bobbio(2004, p. 112)

Hoje, o próprio conceito de democracia é inseparável do conceito de direitos do homem. Se se elimina uma concepção individualista da sociedade, não se pode mais justificar a democracia do que aquela segundo a qual, na democracia, os indivíduos, todos os indivíduos, detêm uma parte da soberania. E como foi possível firmar de modo irreversível esse conceito senão através da inversão entre poder e liberdade, fazendo-se com que a liberdade precedesse o poder?

No âmbito do trabalho humano, evoluiu a consciência de que a força despendida pelo empregado, não mais poderia ser analisada pela exclusiva noção de mera mercadora, imperando o reconhecimento do respeito à liberdade, à autonomia da vontade, do prazer, todos sob a pilastra da dignidade humana, bens jurídicos fundamentais para satisfação do trabalhador, ganhando o reconhecimento do Estado na proteção aos bens imateriais constitucionais.

Para tanto, vislumbra-se a necessidade de conscientizar-se sobre a existência dos direitos de personalidade e sobretudo, dos direitos sociais fundamentais, destinando-se importância e respeito destes, dentro das relaçóes trabalhistas, haja vista, que o trabalho prestado pelo empregado, não visa somente a busca da subsistência e, sim, a prevalência de outros direitos do indivíduo, dentro da sociedade, o que configura o exercício de sua cidadania. O importante é que o trabalhador logre produzir, a fim de arcar com sua subsistência, bem como satisfaça sua realização pessoal, além de ser valorizado no seio da família e da sociedade, vez que, com o trabalho, a produção cresce, e também o poder econômico, o consumo e se atinge o progresso de um país, com a satisfação do operário que se sente mais digno e valorizado pela coletividade. (RUFINO, 2011)

A valorização do trabalhador como indivíduo prima pelo reconhecimento da dignidade humana, um adjetivo intrínseco à condição especial do ser, a qual, se desdobra em outros direitos fundamentais como a liberdade, a igualdade, o exercício da cidadania, restando inconcusso, que o trabalhador não deve ser limitado a uma mercadoria pertencente ao processo produtivo que visa a obtenção do lucro para satisfação dos anseios capitalistas.

Sarlet (2010, p. 37) expressa com precisão o valor da dignidade como qualidade da pessoa humana: 
[...] temos por dignidade da pessoa humana a qualidade intrínseca e distintiva de cada ser humano que o faz merecedor do mesmo respeito e consideração por parte do Estado e da comunidade, implicando, neste sentido, um complexo de direitos e deveres fundamentais que assegurem a pessoa tanto contra todo e qualquer ato de cunho degradante e desumano, como venham a lhe garantir as condiçóes existenciais mínimas para uma vida saudável, além de propiciar e promover sua participação ativa e co-responsável nos destinos da própria existência e da vida em comunhão com os demais seres humanos.

Desta forma, denota-se que o mundo jurídico contemporâneo, não se restringe à reivindicação de proteção da jornada de trabalho, do salário e demais direitos materiais trabalhistas. Luta-se, outrossim, pela proteção dos direitos à personalidade do trabalhador, por uma maior liberdade de trabalho, pela satisfação do trabalhador no ambiente do trabalho, direitos estes não previstos expressamente na legislação especializada (Consolidação das Leis do Trabalho), todavia, reconhecidos em outras normas aplicáveis, e imprescindíveis à valorização do trabalhador. (RUFINO, 2011)

A valorizaçáo dos direitos humanos do trabalhador tornou-se imprescindível, mormente, dos direitos sociais, os quais interferem diretamente na ordem econômica, que é a base do capitalismo de um país federativo como o Brasil, uma vez que, empregados valorizados, são mais eficientes, aumentam o lucro das empresas e movimentam a economia de uma nação.

Nesse esteio, Delgado (2012, p.116) afirma que na sociedade contemporânea:

Não mais se denota que a intervenção estatal de maneira exclusiva é fundamental para prevalência dos direitos fundamentais, podendo ser apenas, de uma adição à atuação coletiva obreira, afirmadora do padrão democrático de gestão trabalhista (...) porque não retira da classe trabalhadora, o essencial senso de cidadania e de sujeito social, nucleares à existência e consolidação de qualquer convivência democrática

Portanto, o reconhecimento da dignidade da pessoa humana, sobretudo do trabalhador, que deve ter respeitado o valor social do trabalho, e o exercício de todos os direitos fundamentais se consolidaram com a Constituição Federal por considerar estes direitos como princípios fundamentais do Estado Democrático de Direito.

O princípio da dignidade da pessoa humana reflete a valorização dos direitos fundamentais e valores primordiais ao constituinte, os quais devem coexistir com o respeito da dignidade humana e com o valor social do trabalho.

Vale (2004, p. 32) entende que os direitos fundamentais são "um conjunto de valores objetivos básicos e, ao mesmo tempo, como marco de proteção de situaçóes jurídicas subjetivas". 
De acordo com a teoria de Carl Schmitt, os direitos fundamentais se classificam em: a) todos aqueles que estão no texto da Constituição; b) todos aqueles que possuem proteção constituinte em virtude da imutabilidade da reforma constitucional. (apud BONAVIDES, 2008)

Para facilitar os estudos e o entendimento, os direitos foram classificados em geraçóes ou dimensóes, como prefere denominar alguns autores, entendendo que do ponto de vista teórico, os direitos do homem nasceram em certas circunstâncias históricas, como os direitos individuais, ligados a ideia de liberdade, ${ }^{1}$ com obrigação negativa do Estado, considerados de primeira geraçáo; os direitos relacionados a igualdade, ou direitos sociais ${ }^{2}$ ou liberdade positiva, considerados de segunda geração e os direitos de solidariedade ${ }^{3}$, fraternidade, os de terceira geração e atualmente, os direitos de quarta geração, que são aqueles que lidam com as mutaçóes do patrimônio genético de cada indivíduo e seus limites. (BOBBIO, 2004)

Verifica-se, pois, que a valorização do trabalhador como ser digno, foi um dos primeiros direitos a ser protegido, e, se baseia nos princípios norteadores de todo ordenamento jurídico, bem como na valorizaçáo dos direitos fundamentais, por conseguinte, de todas relaçóes jurídicas, em especial a trabalhista, devem ser inspirada na valorização do trabalho como respeito àquela qualidade intrínseca do trabalhador, como membro participante de uma sociedade justa livre e solidária.

Esta premissa vai ao encontro dos objetivos fundamentais constitucionais, os quais preconizam e consolidam a relevância do princípio da solidariedade, conforme disposto no art. $3^{\circ}$ da CRFB:

Art. $3^{\circ}$ : Constituem objetivos fundamentais da República Federativa do Brasil:

I - construir uma sociedade livre, justa e solidária;

O reconhecimento desses princípios constitucionais e cumprimento dos objetivos, bem como a valorização do trabalhador, se mostram cada vez mais consolidados ao embasarem os ditames da Ordem Econômica, e da Ordem Social (previstas separadamente pela primeira vez na CRFB/88), tendo por fim assegurar a todos existência digna, nos moldes dos ditames da justiça social:

Art. 170. A ordem econômica, fundada na valorização do trabalho humano e na livre iniciativa, tem por fim assegurar a todos existência digna, conforme os ditames da justiça social, observados os seguintes princípios:

1 Direitos dos cidadãos derivados de sua condição de ser humano

2 O Estado tem o dever de reconhecer e ter açóes positivas frente a este direito

3 Aqueles reivindicados por um movimento social. Pode envolver a questáo da ecologia e meio ambiente 


\section{$[\ldots]$}

Art. 193. A ordem social tem como base o primado do trabalho, e como objetivo o bem-estar e a justiça sociais.

A Constituição Brasileira prevê, ainda, dispositivos mais específicos sobre a noção de dignidade, liberdade humana e dos direitos fundamentais previstos no caput do art. $5^{0^{4}}$, todos interligados aos direitos sociais, previstos no art. $6^{\circ}$ (direito ao trabalho, à saúde, lazer e outros) e a proteção do emprego contra despedida arbitrária, prevista no art. 7o, I, todos, visando a melhoria da condição social.

O trabalhador merece ter sua dignidade respeitada como cumprimento do valor social do trabalho, uma vez que o princípio da dignidade norteia quaisquer direitos, especialmente as garantias fundamentais, servindo como limitador das manobras que possam desvalorizar o trabalhador.

Dessa forma, como dito em primeiro momento, os direitos e garantias individuais (igualdade, liberdade, vida e outros) refletem a abstenção do Estado para não violar ou invadir os direitos dos cidadãos, já os direitos sociais(trabalho, lazer saúde e outros), refletem o modelo de atuação do Estado, a fim de que seja provedor desses direitos, possibilitando a garantia daqueles, notadamente, os de primeira geraçáo.

\section{0 Direito Fundamental ao Lazer nas Relações Privadas Trabalhistas}

As relaçóes trabalhistas, em sua grande maioria, concentram seu foco no tempo em que o indivíduo despende no local de trabalho, produzindo e aumentando o lucro do empregador, olvidando-se contudo, da importância do tempo livre para reestabelecimento do desgaste físico e mental e intelectual do trabalhador, o conhecido "dolce fa niente", expressão italiana que significa o "prazer de não fazer nada", o "prazer dos momentos indolentes".

Em um comparativo ilustrativo com os dizeres da Bíblia, "Deus descansou no sétimo dia”, demonstrando a importância e a relevância de um momento de descanso, sem fazer nada para o reestabelecimento do indivíduo, um momento para contemplar o prazer e a liberdade de agir como quiser.

O sociólogo francês Dumazedier (1976, p. 42) aprofundou-se no estudo sobre o lazer, e entre suas definiçóes sob diversas óticas, conceituou o lazer como:

... um conjunto de ocupaçóes às quais o indivíduo pode entregar-se de livre vontade, seja para repousar, seja para divertir-se, recrear-se e

4 Todos são iguais perante a lei, sem distinção de qualquer natureza, garantindo-se aos brasileiros e aos estrangeiros residentes no País a inviolabilidade do direito à vida, à liberdade, à igualdade, à segurança e à propriedade, nos termos seguintes: 
entreter-se ou, ainda para desenvolver sua informação ou formação desinteressada, sua participação social voluntária ou sua livre capacidade criadora após livrar-se ou desembaraçar-se das obrigaçóes profissionais, familiares e sociais.

Nietzsche (2000) classifica os homens em escravos ou livres, afirmando que escravo é aquele que não tem tempo para si, que faz tudo mecanicamente, podendo ser tanto o empregador, quanto o empregado, desde que tenha limites rígidos na expansão de sua personalidade, vivenciando a mediocridade da rotina sem tempo para refletir, já o homem livre; se configura como aquele que detém a faculdade do controle de seu tempo, fazendo suas escolhas sem obstáculos ou restrições, sem tornar-se um alienado, sem comparar-se à uma máquina pelas açôes mecânicas e rotineiras.

Alguns estudos sociológicos e antropológicos analisam o lazer, traçando um paralelo com o trabalho, como ilustrativamente, a análise demonstrada por Requixa, extraída da observação de palestras e estudos sociológicos, na qual a evolução do lazer se interliga com a necessidade de trabalho. Esclarece que, tratando-se das diversas naturezas de trabalho, como o industrial, o comercial, o doméstico, o escravo, entre outros, todos influenciam com grande relevância, a imprescindibilidade do lazer para o desenvolvimento da sociedade. (REQUIXA, 1977)

Dumazedier (1976) explica a razão pela dicotomia na ideia do exercício de pleno lazer, apontando a não aceitação por parte da ética marxista, dividida em duas correntes: aquela que super valoriza o trabalho produtor das relaçóes sociais e caminho de formação do homem; e a segunda, que acentua mais o tempo fora do trabalho como um produto do progresso do próprio trabalho, como o direito "à preguiça”.

Contudo, defende o exercício do lazer observando que : "o trabalho é o império da necessidade; é fora dele que começa a liberdade", conforme descrição de Marx no clássico "Capital" e ainda enfoca as assertivas de Lafargue que ilustrou Deus, como o próprio modelo da preguiça ideal: "Jeová, este Deus barbudo e carrancudo, dá a seus adoradores o supremo exemplo da preguiça ideal, depois de seis dias de trabalho repousou para a eternidade" deixando irrefutável a importância do descanso para lazer. (REQUIXA, 1977, p. 51)

Requixa (1977, p. 51) contextualiza a análise do lazer perante a sociedade em três fases: primeiramente, nega-se sua relevância, através de diferentes argumentos; em seguida, o lazer "é percebido como importante face ao seu potencial terapêutico em relação a outras problemáticas urbanas, ou seja, dentro de um sentido instrumental"; e posteriormente, "percebe-se que o lazer é importante em si mesmo". Esclarece, pois, que o processo de urbanização e industrialização das sociedades capitalistas, não pode ser observado sem a ótica da importância do lazer.

Complementando essa análise, Requixa (1977, p. 52) aponta alguns efeitos de um foco e respeito maior ao "direito ao lazer": 
- O grande número de pessoas que trabalhavam como profissionais, ou voluntários em obras sociais, passaram a sentir a importância do trabalho que realizavam no campo do lazer. Sentiram-se profissional, pessoal e socialmente valorizados;

- A assinalada promoção do tema lazer, não apenas junto aos técnicos, mas também junto ao grande público, através da imprensa, a qual apresentou farto noticiário a respeito dos assuntos tratados;

- Provocou-se atençáo dos próprios trabalhadores sociais para uma nova forma de trabalho social, através das atividades de lazer, com todas as suas possibilidades insuspeitadas;

- A ampliação da concepção do lazer, concernente a todas as faixas etárias, não se confundindo apenas com atividades infantis;

- A própria palavra lazer passou a fazer parte do vocabulário de profissionais da área do social e integrou-se, com destaque, no vocabulário da imprensa

Considerando que esta análise foi realizada no Brasil, precisamente na regiáo da Capital Paulista, nas décadas de 1960 e 1970, paulatinamente, verificou-se, a importância do tempo livre, da liberdade de escolher qual atividade praticar ou simplesmente, não praticar qualquer atividade, o que ganhou relevância para todos os seres humanos, notadamente, para o trabalhador.

O tempo livre, é aquele em que o indivíduo escolhe suas atividades, de acordo com o que lhe satisfaz, é o momento do desfrute ao lazer, direito fundamental para o pleno desenvolvimento do ser humano, notadamente, do trabalhador.

Visando a importância deste tempo livre destinado ao lazer, a Declaração de Direitos Humanos de 1948 normatizou este bem jurídico, como sendo fundamental a todos os trabalhadores:

Artigo XXIV - Todo ser humano tem direito a repouso e lazer, inclusive à limitação razoável das horas de trabalho e a férias remuneradas periódicas.(g.n.)

Assim, considerando a influencia da referida Declaração na redação da Constituição Democrática Brasileira de 1988, o legislador constituinte inseriu o direito ao lazer no capitulo dos Direitos Sociais, elevando o status deste direito, a um direito fundamental do cidadão, haja vista, sua essencialidade ao desenvolvimento físico, psíquico e intelectual de todos indivíduos, especialmente, dos trabalhadores.

No mesmo esteio, o Pacto Internacional dos Direitos Econômicos, Sociais e Culturais, o qual o Brasil firmou como signatário dispóe em seu art. $7^{\circ}$ : 
Os Estados integrantes do presente Pacto reconhecem o direito de toda pessoa a desfrutar condições de trabalho justas e favoráveis, que garantam, sobretudo:

(...)

d) O repouso, os lazeres, a limitação razoável da duração do trabalho e férias remuneradas periódicas, assim como remuneração dos feriados. (g.n.)

Verifica-se, pois, que o direito ao lazer é um direito social, fundamental ao ser humano, considerado de segunda geração, que decorre dos direitos de primeira geração, sempre embasados na dignidade da pessoa humana, nos moldes explicitados por Martins(2012, p. 57):

Os direitos do segundo grupo são os direitos econômicos, sociais e culturais, bem como os direitos coletivos e das coletividades. Decorrem do princípio da igualdade. É a ideia do Estado do Bem-Estar Social, com caráter individualista.

Neste contexto, observa-se que os direitos sociais, mormente, o direito ao lazer, não se limitou ao campo normativo internacional, passando para a esfera constitucional, conforme citado em um primeiro momento, iniciando-se o capítulo dos Direitos Sociais pelo art. $6^{\circ}$ da Constituição Federal que preconiza:

Art. 60 São direitos sociais a educação, a saúde, a alimentação, o trabalho, a moradia, o lazer, a segurança, a previdência social, a proteção à maternidade e à infância, a assistência aos desamparados, na forma desta Constituição. (g.n.)

Estando inserido este capítulo no Título dos Direitos e Garantias Fundamentais, quedou-se insofismável a natureza dos direitos sociais, como relevantes ao desenvolvimento e fundamentais do cidadão, bem como, a irrefragável força normativa desses direitos, os quais mudaram a forma de dialogar das constituiçóes brasileiras ao longo de sua história, vez que, enquanto na época da ditadura militar a constituição dialogava com o Estado, com a promulgação da Constituição Democrática de 1988, passou a dialogar com a sociedade, ancorada nos direitos fundamentais, notadamente, na dignidade humana, priorizando o interesse dos indivíduos da sociedade e só posteriormente, os interesses do Estado.

Desta forma, esses direitos passaram a se configurar como preceitos que subordinam a sociedade, o Estado e os particulares, nos moldes ressaltados por Sarlet (2010, p. 38):

Há de acolher, portanto, a lição de Vieira de Andrade, quando destaca os dois principais e concorrentes da problemática, quais sejam, a construção de que os direitos fundamentais, na qualidade de princípios constitucionais e por força do princípio da unidade do ordenamento jurídico, se 
aplicam relativamente a toda a ordem jurídica, inclusive privada, bem como a necessidade de se protegerem os particulares também contra atos atentatórios aos direitos fundamentais provindos de outros indivíduos ou entidades particulares.

Assim, inquestionável a relevância dos direitos fundamentais nas relaçóes trabalhistas, sobretudo, os direitos sociais, os quais por vezes, quedam-se no esquecimento de sua validade e aplicação em relaçóes desta natureza, por visarem primordialmente o aumento na lucratividade e a busca da subsistência.

As relaçóes de trabalho envolvem sujeitos em condição de desigualdade, o trabalhador, considerado hipossuficiente e o empregador, autossuficiente, justificando a intervenção estatal a fim de evitar os abusos nos desmandos da parte mais forte, o empregador, a fim de prevalecer o equilíbrio na balança da Justiça.

Com efeito, coube ao Estado efetivar a tutela do trabalhador através de direitos previstos em norma de ordem pública, descritos na Constituição Federal como direitos fundamentais, dentre os quais, salienta-se os direitos tutelados no art. $7^{\circ}$ que visam melhores condiçôes de trabalho sob a ótica material e econômica.

Sem dúvida, o principal anseio de um trabalhador é o valor de seu salário e dos demais benefícios de ordem material, enquanto o empregador visa o aumento de sua produtividade e lucratividade oriunda da energia gasta com força de trabalho de seu empregado.

Em virtude do conflito de interesses entre a "mais valia"(força de trabalho) e o capital (busca do lucro), a tendência é que o empregador almeje o aumento de sua produtividade exigindo, por vezes, de forma abusiva, o empenho e a dedicação da força de trabalho do empregado, o qual, acaba se submetendo às diversas formas de abusos, no anseio de receber um acréscimo em seu salário, como peculiarmente, o adicional de horas extras, que acaba "comprando" não só a saúde do trabalhador, mas também, os poucos momentos de lazer e descanso, que o obreiro poderia passar com sua família.

Paralelamente, a cultura brasileira de primar por um aumento nos ganhos e ostentação de bens materiais, acarreta na busca de maiores salários por parte do trabalhador, submetendo-se à jornadas excessivas a fim de não resistir aos ditames do empregador e em contrapartida, aumentar seu salário para obtenção de bens e melhora no estilo de vida, sendo conivente com o empregador que menospreza as premissas que direcionam a solidariedade do contrato de trabalho.

A visão social do contrato de trabalho se solidificou com art. 421 do Código Civil que dispõe: "A liberdade de contratar será exercida em razão e nos limites da função social do contrato".

Desde então, o contrato laboral, não mais pode ser interpretado na concepção individualista de um instrumento jurídico hábil a satisfazer interesses das partes, ensejou 
uma interpretação dentro de um contexto social, de forma exógena, como percursor do bem comum, sendo analisado não exclusivamente pelos aspectos formais (objeto capaz, objeto lícito e forma prescrita em lei), releva-se também outras questóes igualmente importantes como a relação com o ambiente, às questóes sociais e as morais.(PAMPLONA FILHO, 2005)

Se a função social do contrato restringe a liberdade de contratação nas relaçóes privatísticas, com maior razão, no contrato de trabalho, em que as partes são desiguais, imperando uma proteção do Estado ao hipossuficiente, através do protecionismo, na busca do equilíbrio e do respeito ao fundamento do valor social do trabalho.

Esse respeito culmina no exercício do direito-função ${ }^{5}$ do empregador, focando o interesse da comunidade dos seus funcionários, sensível à participaçáo obreira no contexto empresarial interno, o que desvia da antiga concepção do individualismo. (DELGADO, 2010)

Dessa forma, se o Estado foi criado para concretizar esses valores essenciais, as normas criadas por ele, sejam constitucionais ou infraconstitucionais, devem respeitar esses objetivos, fazendo do bem social, a finalidade precípua das regras criadas na ordem jurídica, e por consequência, das regras que regem o contrato de trabalho.(RUFINO, 2011)

O contrato de trabalho, como instrumento das relaçóes entre trabalhador e empregador deve buscar a inserção daqueles valores na sociedade, sob o prisma da probidade e da boa-fé, restando imprescindível a valorização do trabalhador, o que cria impacto direto na ordem econômica do país, a qual fundada na valorização do trabalho humano, visa assegurar a todos existência digna dentro dos ditames da justiça social. Desse modo, a base do capitalismo que apregoa a nossa Constituição é também a livre iniciativa, o que enseja a busca do lucro a tudo custo por parte dos empresários, por outro lado, empregados mais respeitados em sua dignidade e direitos fundamentais e estimulados ao respeito dos intervalos necessários para sua recuperação, produzirão com mais efetividade, e certamente, o lucro da empresa aumentará e a economia do país sentirá os benefícios dessa equação. (RUFINO, 2011)

Se é dever do Estado concretizar esses valores essenciais, as normas jurídicas por ele estipuladas, devem cumprir os objetivos constitucionais, fazendo do bem comum, o fundamento das regras jurídicas que regem o contrato de trabalho. (RUFINO, 2011)

Miranda (1998, p. 166) afirma "A Constituição confere uma unidade de sentido, de valor e de concordância pública ao sistema dos direitos fundamentais. E ela repousa na dignidade da pessoa humana, ou seja, na concepçáo que faz a pessoa fundamento e fim da sociedade e do Estado".

5 Poder atribuído ao titular para agir em tutela de interesse alheio, e não de estrito interesse próprio 
O desrespeito às garantias fundamentais por parte do empregador, sobretudo, o desrespeito à dignidade do trabalhador, e os entraves ao pleno exercício dos direitos sociais, desvirtua a finalidade do Estado, violando todos os princípios e normas de nosso ordenamento, notadamente, a função social da empresa.

A observância à dignidade do trabalhador e de todos seus direitos fundamentais por parte do empregador é essencial ao alcance dos valores da justiça, impostos pela ordem jurídica. Nesse sentido, preleciona Piovesan (2010, p. 98):

O valor da dignidade humana impóe-se como núcleo básico e informador do ordenamento jurídico brasileiro, como critério e parâmetro de valoração a orientar a interpretação e compreensão do sistema constitucional instaurado em 1988. A dignidade humana e garantias fundamentais vêm a constituir os princípios constitucionais que incorporam as exigências de justiça e dos valores éticos, conferindo suporte axiológico ao sistema jurídico brasileiro. Os direitos e garantias fundamentais passam a ser direitos de uma especial força expansiva, projetando-se por todo o universo constitucional e servindo como critério interpretativo de todas as normas do ordenamento jurídico nacional.

Percebe-se, pois, que o empregador passa a ter um importante papel na sociedade, pois o reconhecimento e o respeito pela pessoa humana que é por ele contratado, influencia todo o contexto social.

A denominada função social da empresa resta inserida em um processo democrático, o qual busca preservar o conceito de cidadania, enfatizando os direitos individuais e sociais, ambos extremamente relevantes à ordem social, a qual deve ser dimensionada pelo princípio maior da dignidade humana e do valor social do trabalho. (PIOVESAN, 2010)

Diante deste contexto, as relaçóes de trabalho não podem ser analisadas sob a ótica exclusiva dos direitos materiais oriundos da contraprestação laboral, deve-se primar pela prevalência dos direitos fundamentais do trabalhador, especialmente aqueles que se destinam à recuperação da energia gasta no trabalho e do desenvolvimento do indivíduo em sua plena realização, como o direito ao lazer.

\subsection{O Excesso da Jornada de Trabalho e a Violação do Direito ao Lazer}

Existe uma crença de que o trabalho em jornada extraordinária beneficia tanto o empregador quanto o trabalhador. Aquele, por usufruir de mais tempo da força de trabalho de seu empregado, culminando no aumento da produtividade e do lucro, e esse, por requestar um acréscimo em seu salário, ante a realidade econômica, o que possibilita um aumento de seu ganho através do trabalho extraordinário, por vezes, sem limites plausíveis, beirando a insanidade. 
Diante da premissa de que o trabalho dignifica, o qual foi inserido, sobretudo, no rol dos direitos fundamentais dos cidadãos, o trabalhador se submete a horas excessivas de trabalho, na busca de receber um "plus" ao salário, ou, mesmo em desacordo em seu íntimo, se dispóe a trabalhar em jornadas excessivas quando requisitado pelo empregador, a fim de preservar sua colocação na empresa.

No entanto, considerando a dependência que o trabalhador encontra-se perante o empregador e o capitalismo selvagem, de grande concorrência, face as circunstâncias da economia mundial, impera-se uma regulamentação por parte do Estado, a fim de limitar este excesso de jornada, com a finalidade de proteger a saúde e o equilíbrio dos trabalhadores, obstaculizando o trabalho extraordinário além da $2^{\text {a }}$ hora excedente, conforme previsão no diploma celetista:

art. 59 da CLT : A duração normal do trabalho poderá ser acrescida de horas suplementares, em número não excedente de 2 (duas), mediante acordo escrito entre empregador e empregado, ou mediante contrato coletivo de trabalho.

Martins (2012, p. 522) esclarece que a intenção do Estado em limitar a jornada foi criar um descanso mínimo ao trabalhador a fim de que náo seja forçado a prestar serviços em jornadas extensas, aguçando os prejuízos à sua saúde:

A natureza jurídica da jornada de trabalho abrange dois aspectos. Num primeiro plano, tem natureza pública, pois é interesse do Estado limitar a jornada de trabalho, de modo que o trabalhador possa descansar e não venha prestar serviços em jornadas extensas. Num segundo momento, tem natureza privada, visto que as partes do contrato de trabalho podem fixar jornadas inferiores às previstas na legislação ou nas normas coletivas. A legislação apenas estabelece o limite máximo, podendo as partes fixar limite inferior.

Com efeito, o legislador limitou a prorrogação da jornada em 02 horas e eximiu o recebimento da paga extraordinária somente nos casos que houver compensação legal, como a semanal que compensa a ausência de trabalho no sábado, excepcionando este limite apenas em casos de necessidade imperiosa, nos moldes do art. 61 da CLT.

Contudo, existe entendimentos de que o art. 59 supra sequer fora recepcionado pela Suprema Lei, vez que admite o labor em tese extraordinário, de forma ordinária, o que configuraria um paradoxo desfavorável ao trabalhador.

Por conseguinte, muitos consideram inadmissível tratar de labor extraordinário, que significa, aquele que não ocorre de forma corriqueira, cotidiana, como uma ocorrência comum e habitual, absolvida pelo pagamento do adicional constitucional, distinguindo, sobretudo, a jornada extraordinária, aquela "paga" com o adicional de no mínimo 50\%, da jornada excessiva. 
Neste sentido, Souto Maior (2013) assevera importante crítica à esta prática dicotômica:

Importante explicar que a limitação ao adicional de $50 \%$ (cinquenta por cento), para o pagamento das horas extras, somente tem sentido se as horas são, efetivamente, extras, isto é, horas além da jornada normal, prestadas de forma extraordinária. Quando as horas extras se tornam ordinárias, deixa-se o campo da normalidade normativa para se adentrar o campo da ilegalidade e, neste sentido, apenas o pagamento ao adicional não é suficiente para corrigir o desrespeito à ordem jurídica.

Nesse sentido, verifica-se que a prática reiterada e cotidiana do labor extraordinário, não deve ser apenado apenas com a paga extraordinária, mas outrossim, com a imposição de multas e sançóes correspondentes pelos auditores do trabalho, em razão da complexidade maléfica aos direitos fundamentais do trabalhador.

As empresas buscam elevar o número de horas trabalhadas por seus funcionários, mormente, de forma habitual, a fim de reduzir o gasto com novas contrataçóes, no intuito de economizarem e levarem vantagens sobre as concorrentes no mercado competitivo, contudo, esta "vantagem" para a empresa empregadora acarreta diversas desvantagens ao trabalhador, o qual tem sua saúde prejudicada e, sobretudo, seu momento de lazer, de total autonomia e liberdade em seu tempo livre, para prática de condutas prazerosas e desfrute do contato familiar e entes queridos.

Foi noticiado no CONJUR(2015) a empresa Magazine Luiza foi condenada a pagar $\mathrm{R} \$ 100.000,00$ (cem mil reais) de indenização (Processo nº 0010912-03.2014.5.15.0041 que tramitou perante a MM. Vara do Trabalho de Itapetininga-SP) por exigir de seus empregados, trabalho habitual em jornada excessiva, mesmo após ter sido atuada pela fiscalização por constantemente obrigar seus empregados a extrapolarem o limite legal de duas horas diárias sem qualquer justificativa legal, conforme fundamentou o procurador do trabalho Gustavo Rizzo Ricardo:

O modelo de produção adotado pelo Magazine Luiza, fundado no binômio custo e máximo lucro, inclusive com excesso nas jornadas de trabalho, viola os valores sociais do trabalho e o respeito à dignidade do ser humano, com previsão na Constituição Federal.

(...)

Trata-se de um modelo de 'dumping social', onde determinada empresa deixa de cumprir, de forma reiterada, inescusável e consciente as obrigaçôes trabalhistas básicas, com a intenção de reduzir custos e, por consequência, aumentar seus ganhos. Isso gera prejuízos aos concorrentes cumpridores das obrigaçóes laborais e os incentiva a atuarem do mesmo modo. 
Desse modo, a empresa não cumpre sua função social, haja vista, que como detentora do poder diretivo da força de trabalho, tem a obrigação de reprimir qualquer prática que atente contra legislação protetiva do trabalho, notadamente, que afronte os direitos fundamentais do trabalhador, entre esses, o direito social do lazer.

No sistema organizacional contemporâneo, os empregadores exigem sempre um maior empenho e dedicação dos trabalhadores, não só no critério qualitativo, mas, outrossim, quantitativo de tempo a disposição, acarretando no stress do trabalhador, com cobranças e pressóes a todo momento, para produzirem mais em menos tempo, num total menosprezo à saúde e aos direitos fundamentais do obreiro, sequer cogitando-se o respeito ao lazer do empregado. (RUFINO, 2011)

No entanto, deve-se atentar pela condição humana do trabalhador, o qual, não se reduz ao caráter meramente animal que vive para sua subsistência. $\mathrm{O}$ trabalho é a diretriz do mundo industrial responsável pelo desenvolvimento das atividades econômicas, especialmente, no capitalismo, como o que vigora no Brasil, incutindo nos trabalhadores a falsa percepção de que tempo livre, implica na ausência de produção, caminhando na contramão do desenvolvimento econômico e financeiro, e por consequência, sugere que a possível liberdade do tempo ocioso seja substituída pela busca de ganhos materiais suplementares. (CALVET, 2006)

A partir desta equivocada premissa, os indivíduos passam a analisar a liberação do tempo livre como negação ao trabalho ou à responsabilidade de cidadão, que deve impulsionar o desenvolvimento econômico de uma naçáo, focando a produtividade no trabalho como cerne de todas as atividades que cercam o entorno da vivência do ser humano, esquecendo-se, contudo, que o pleno exercício ao lazer auxilia não só, à preservação ou recuperação da saúde do trabalhador, bem como, estimula a criatividade, o intelecto, a liberdade, o pluralismo de pensamento, e resgata as relaçóes emocionais, tanto as pessoais, quanto as profissionais, edificando não só, o exercício dos demais direitos basilares da sociedade, como a liberdade, a família, a fraternidade, como singularmente, os direitos do trabalhador, como a vida, a saúde, a cultura e todos os demais, intrínsecos ao ser humano.

Atento a essas necessidades, o legislador impôs a observância dos intervalos de descansos, sejam intrajornadas, sejam interjornadas, propondo sobretudo, que no mínimo uma vez por semana, o trabalhador tem direito a 24 horas sem pensar em trabalho, a fim de possibilitar o convívio familiar, haja vista, a imposiçáo de revezamento dos descansos semanais aos domingos, conforme previsão do art. 66, 67, e 71 e outros do diploma celetista.

Entretanto, esses momentos de descanso, não devem ser preenchidos exclusivamente com outras atividades ligadas ao desenvolvimento do intelecto, como estudos, aperfeiçoamentos, na busca de melhores condiçóes de trabalho, especialmente, ao considerar, que 
tais práticas favorecerão a fadiga do assoberbado trabalhador, colocando em risco a preservação de sua saúde, da segurança do trabalho e violando de forma inconteste o pleno exercício do lazer.

Neste sentido, assevera Calvet (2006, p. 57) demonstra a importância do respeito a este direito fundamental:

O lazer é direito social de todos os trabalhadores, subordinados ou não, possuindo dois aspectos: econômico e humano. A todos os trabalhadores reconhece-se a necessidade de uma limitação da duração do trabalho e o direito ao gozo do lazer, o que implica uma alteraçáo na interpretaçâo de institutos previstos na ordem infraconstitucional e na conduta do tomador do serviço, reconhecendo-se a posição jurídica subjetiva ao trabalhador de obtenção de tutela judicial com eventual reparação por dano imaterial sempre que lesionado esse valor, tanto na relaçáo de emprego quanto nas demais relaçóes privadas de trabalho, estas na medida de hipossuficiência do trabalhador.

Denota-se, pois, a importância da valorização dos momentos livres, sem qualquer atividade ou responsabilidade, que permita ao trabalhador/cidadão, o pleno exercício de seus interesses mais basilares, como o cuidado com a saúde e a convivência com os entes queridos.

Somente a partir do reconhecimento da importância do lazer na vida do trabalhador, ou de qualquer cidadão, vislumbrará o pleno exercício da liberdade, da vida, do bem estar, e por consequência, da paz social.

A problemática instala-se no receio ao desemprego, que enseja na cumulação de trabalho por parte do empregado, o qual dedica-se exclusivamente ao trabalho ou a condiçóes que propiciam sua permanência no emprego, acarretando em um desgaste físico e mental que afeta sua saúde e seu desenvolvimento sobre os vários aspectos dentro da sociedade. (RUFINO, 2011)

Nessas situaçóes, o indivíduo fica impossibilitado de atuar dentro dos padróes de normalidade, aceitos como tais em seu ambiente, e isto se torna perceptível para as pessoas no trabalho, as quais observam a alteração comportamental da vítima. (FIORELLI, 2003)

Inconteste que toda esta pressão e exigência exacerbada pode ocasionar a uma alteração de comportamento do empregado, o qual, estressado por tanta dedicação ao trabalho sem minimamente extravasar a pressão acumulada, sem reservar para si um tempo dedicado ao seu lazer pleno, acaba atraindo distúrbios e outros prejuízos que afetam seus bens mais intrínsecos, podendo gerar, mormente, a práticas violentas.

Em razão destas alterações, além dos prejuízos fisiológicos, o indivíduo passa a sofrer prejuízos funcionais, tornando-se incapaz de responder aos estímulos normais de suas 
atividades, pela apresentação de comportamentos inaceitáveis para com os que com ele convivem. (FIORELLI, 2003)

Portanto, cabe ao empregado assumir uma posição jurídica subjetiva de postular a tutela jurisdicional em razão da ameaça ou lesão ao direito ao lazer oriundo das práticas cometidas pelo empregador, pretendendo no primeiro caso uma tutela inibitória com fixação de multa para que o empregador não adote a referida conduta, somada ao pedido de reparação pela dano causado pelo empregador, que por tratar-se de valores imateriais, gerarão uma indenização com caráter de compensação, através da indenização por danos morais, arbitrado pelo órgão judicial. (CALVET, 2006)

\section{A Responsabilidade do Empregador pela Violação do Direito ao Lazer do Trabalhador}

Conforme analisado em um primeiro plano, o contrato de trabalho possui uma função social, responsabilizando o empregador ao cumprimento da solidariedade contratual.

A solidariedade contratual pode ser entendida como uma negação da autonomia da vontade no prisma voluntarista e egoística, além de aguçar a autonomia privada, evoluindo do Estado Liberal para o Estado Social, ensejando uma concepção contratual mais social do que individual. (DALLEGRAVE NETO, 2009)

A aplicação da solidariedade contratual e a função social do contrato se originam de diversos dispositivos como o art. $1^{\circ}$ III e IV (princípio fundamental a dignidade humana e valor social do trabalho), $3^{\circ}$ I e IV (objetivo fundamental como uma sociedade justa e solidária e sem discriminação), art. 170 III (função social da propriedade) e art. 193 (bem estar e justiça social como primado ao trabalho) da CRFB, aplicando-se, pois, às relaçóes de trabalho.

Esses comandos constitucionais, se entrelaçam na concepção das relações de trabalho sob a ótica da dignidade do trabalhador, da função social do contrato de trabalho, e do primado do trabalho, este último, cerne da ordem social.

A hermenêutica impóe que a leitura dos dispositivos fundamentais busque a unidade constitucional e a supremacia destas leis sobre aquelas infraconstitucionais, sobretudo, no caso de antinomia, impondo-se a interpretação sistemática, lógica e gramatical, a fim de primar e harmonizar a valorização dos direitos do trabalhador dentro da ordem econômica, com a preservação dos direitos fundamentais.

No momento da elaboração da Carta Constituinte, a sociedade, através de seus representantes legislativos, resolveu criar mecanismos que possibilitem a proteção dos cidadãos, mormente, do trabalhador, socializando os encargos através da ótica social que limita o capitalismo selvagem, impondo direitos sociais que devem ser respeitados pelo Estado 
e pelo empregador, ambos com responsabilidades, este último, com responsabilidades no caso de dolo ou culpa, não eximidas pelo constituinte e pelo legislador infraconstitucional ao imputar, com base na solidariedade do contrato de trabalho, o dever de indenizar no caso de prejuízos oriundos de imprudência, negligência ou imperícia ocorridas no decorrer do contrato de trabalho.

No tocante à satisfação do dano decorrente da inexecução do contrato de trabalho, é que a base jurídica se alicerça no respeito aos direitos existenciais ou fundamentais, alargando as hipóteses de responsabilidade civil objetiva do empregador como tendência à inversão da ordem geral, considerando a máxima tutela da vítima, no caso, o trabalhador. (DALLEGRAVE NETO, 2009)

Os danos sofridos pelos trabalhadores em virtude da não observância da função social da empresa e do contrato de trabalho, abrangem, não somente aqueles ocorridos dentro da empresa, mas também, prejuízos decorrentes ao desrespeito de normas mínimas de tutela do trabalhador, as quais infringem direitos garantidos pelo Estado Democrático de Direito.

Desse modo, o excesso de jornada que viola não somente a saúde do trabalhador, e a ausência de intervalo hábil a sua recuperação físico-psíquica, mas notadamente, o direito ao lazer, ao tempo livre, a convívio com a família, sem qualquer limitação à sua vida fora do ambiente do trabalho, deve ser responsabilizado pelo empregador, haja vista, o descumprimento da função social do contrato de trabalho e a inobservância da solidariedade social, dificultando a inserção social deste trabalhador.

Por conseguinte, a ausência de tempo livre, que proporcione ao trabalhador, o convívio familiar sem ter que se abster dos momentos prazerosos com os entes queridos, ou, a inexistência de qualquer obrigação, direta ou indiretamente (como estudos para melhorar a qualificação, continuidade do trabalho no domicílio e outros) relacionada ao trabalho, que obstaculize o pleno exercício do lazer, correlaciona-se diretamente ao abuso nas exigências do empregador, e desrespeito à função social do contrato, ensejando, consequentemente, a responsabilização desse último, em indenizar os danos existenciais do trabalhador.

Conforme assertivas de Calvet (2006, p. 59) o lazer está umbilicalmente ligado aos direitos existenciais:

Como se viu em sua conceituação, o lazer possui várias perspectivas, sendo antes de mais nada um estado da existência humana, podendo-se concluir, nesse aspecto, que sua esfera de atuação gravita em torno de direitos extrapatrimoniais do ser humano, como um bem imaterial que a ordem constitucional reconhece como valor intrínseco ao próprio ser humano a fim de manter sua dignidade. 
Tratando-se pois, de valor intrínseco do indivíduo, mormente, do trabalhador, caberá ao empregador indenizar o dano extrapatrimonial decorrente do excesso de trabalho e jornada, acarretando na indenização por ato ilícito pregada no Código Civil:

Art. 186. Aquele que, por ação ou omissão voluntária, negligência ou imprudência, violar direito e causar dano a outrem, ainda que exclusivamente moral, comete ato ilícito.(g.n.)

Art. 187. Também comete ato ilícito o titular de um direito que, ao exercê-lo, excede manifestamente os limites impostos pelo seu fim econômico ou social, pela boa-fé ou pelos bons costumes. (g.n.)

Neste prisma, a jornada excessiva, deve ser analisada de forma macro em relação a concepção da jornada extraordinária, vez que sua ocorrência é cotidiana e habitual, violando os limites de jornada, a redução dos intervalos, além de outras tutelas fundamentais como a saúde, integridade psicológica, vida, valores essenciais ao ser humano, protegidos pela limitação do trabalho. Aliás, sequer foi criada a hipótese de flexibilização de redução de intervalos, salvo na hipótese em que a empresa tiver refeitório próprio e possibilitar a saída antecipada, com o fim primordial, da garantia plena do usufruto de momentos de descanso e lazer como caminho percursor dos demais direitos existenciais do trabalhador.

À guisa de ilustração e corroboração, a indenização por danos existenciais quando da violaçáo do direito ao lazer do trabalhador por excesso de jornada, tem sido reconhecida pelos tribunais, os quais, paulatinamente, têm admitido esta hipótese jurídica como vértice do direito fundamental ao lazer:

EMENTA: "DANO EXISTENCIAL. NEGATIVA DE DIREITO AO LAZER E DESCASO. INDENIZAÇÃO PELOS DANOS MORAIS DEVIDA. O direito ao lazer e ao descanso é direito humano fundamental, assegurado constitucionalmente - art. 6o - e está diretamente relacionado com a relação de trabalho. A prorrogação excessiva da jornada de trabalho justifica a indenização compensatória pelo dano causado. Trata-se de desrespeito contínuo aos limites de jornada previstos no ordenamento jurídico, sendo, pois, ato ilícito. É o chamado dano existencial, uma espécie de dano imaterial em que o trabalhador sofre limitaçóes em sua vida fora do ambiente de trabalho" ( TST - Precedente processo 01924-2011-113-03-00-2, Relator Juiz Convocado Paulo Eduardo Queiroz Gonçalves, publ. 11/12/2013).

DANO EXISTENCIAL. DANO MORAL. DIFERENCIAÇÃO. CARGA DE TRABALHO EXCESSIVA. FRUSTRAÇÁO DO PROJETO DE VIDA. PREJUÍZO À VIDA DE RELAÇÓES. O dano moral se refere ao sentimento da vítima, de modo que sua dimensão é subjetiva e existe in re ipsa, ao passo que o dano existencial diz respeito às alteraçôes prejudiciais no cotidiano do trabalhador, quanto ao seu projeto de vida e suas relaçóes sociais, de modo que sua constatação é objetiva. 
Constituem elementos do dano existencial, além do ato ilícito, o nexo de causalidade e o efetivo prejuízo, o dano à realização do projeto de vida ou o prejuízo à vida de relaçóes. Caracteriza-se o dano existencial quando o empregador impóe um volume excessivo de trabalho ao empregado, impossibilitando-o de desenvolver seus projetos de vida nos âmbitos profissional, social e pessoal, nos termos dos artigos 60 e 226 da Constituição Federal. O trabalho extraordinário habitual, muito além dos limites legais, impóe ao empregado o sacrifício do desfrute de sua própria existência e, em última análise, despoja-o do direito à liberdade e à dignidade humana. Na hipótese dos autos, a carga de trabalho do autor deixa evidente a prestação habitual de trabalho em sobrejornada excedente ao limite legal, o que permite a caracterização de dano à existência, eis que é empecilho ao livre desenvolvimento do projeto de vida do trabalhador e de suas relaçóes sociais. Recurso a que se dá provimento para condenar a ré ao pagamento de indenização por dano existencial.( TRT-PR-281612012-028-09-00-6-ACO-40650-2013 - 2a . TURMA Relator: ANA CAROLINA ZAINA Publicado no DEJT em 11-10-2013)

É cediço, que muitas empresas desrespeitam o princípio protecionista do trabalhador, com diversas práticas ilícitas, sobretudo, com a exigência desenfreada de trabalho sem limites de jornada ou respeito às pausas legalmente previstas, visando o aumento da produtividade, mesmo diante da inconcussa agressáo aos direitos humanos dos trabalhadores, o que se denomina dumping social, o qual, somente será freado, se o Estado impor as sançóes correspondentes, a fim de viabilizar e assegurar a função social do contrato de trabalho.

Souto Maior (2013) critica a busca da lucratividade irracional e desproporcional por parte do empregador em detrimento aos direitos fundamentais do trabalhador:

A pertinência desses dispositivos no direito do trabalho é gritante, pois, normalmente, as agressóes ao direito do trabalho acabam atingindo uma grande quantidade de pessoas, sendo que destas agressóes o empregador muitas vezes se vale para obter vantagem na concorrência econômica com outros empregadores. Isto implica, portanto, dano a outros empregadores que, inadvertidamente, cumprem a legislação trabalhista, ou, de outro modo, acaba forçando-os a agir da mesma forma, precarizando, por completo, as relaçóes sociais, que se baseiam na lógica do capitalismo de produção. Óbvio que esta prática traduz-se em "dumping social”, que prejudica a toda a sociedade e óbvio, igualmente, que o aparato judiciário não será nunca suficiente para dar vazão às inúmeras demandas em que se busca, meramente, a recomposiçáo da ordem jurídica, o que representa um desestímulo para o acesso à justiça, forçando a prática dos acordos trabalhistas, e tudo somado acaba constituindo mais um incentivo ao descumprimento da ordem jurídica. 
Portanto, o Estado deve inibir esta prática que prejudica não só os trabalhadores, mas toda a sociedade, computando, sobretudo, a gravidade do dumping social ou do desrespeito ao direito ao lazer do trabalhador, na fixação da indenização, a fim que amenize o prejuízo do trabalhador, atinja o caráter pedagógico e evite a perpetuação da prática ilícita.

Ademais, o ilícito praticado pelo empregador, viola o pleno exercício da cidadania por parte do trabalhador, o qual se encontra com limitaçóes no usufruto de seus direitos. Considerando que o principio da cidadania consiste no "direito a ter direitos", sem dúvida, o ilícito que viola entre outros, o direito ao lazer do empregado, restringe outrossim, seu papel como cidadão, em seus valores mais intrínsecos, ensejando, pois, o pagamento de uma indenização por danos morais.

No tocante aos parâmetros para fixação da indenização, Delgado (2012) classifica em 05 (cinco), os critérios essenciais para a fixação do quantum: a) verificar a natureza do ato ofensivo (se é exclusivamente civil ou também penal; sua gravidade e o bem jurídico violado); b) a relação do ato com a comunidade (intensidade, repercussão); c) a pessoa do ofendido (posição familiar, política, comunitária; nível de escolaridade); d) a pessoa do ofensor (sua posição socioeconômica; ocorrência de práticas reiteradas; intensidade do dolo ou culpa); e) existência ou não de retratação espontânea por parte do ofensor.

Para uma fixação razoável e equilibrada, a fixação do montante indenizatório deve observar um juízo de equidade, razoabilidade, e imparcialidade do julgador, e, se possível, fixação por arbitramento anelando os dispositivos constitucionais (art. $5^{\circ} \mathrm{V}$ e X e 7o, XXVIII) e infraconstitucionais (art. 944 CCB). (DALLEGRAVE NETO, 2004)

Assim, a fixação de uma importância coerente e razoável ä guisa de indenização por danos existenciais, é essencial para cumprir a finalidade de evitar a prática de reincidência do empregador e atenuar os efeitos da ausência de lazer na vida do trabalhador, lembrando que a paga respectiva não substitui a subtração desse direito fundamental ao ser humano, contudo, pode inibir o empregador a exigir o trabalho de forma excessiva e abusiva, proporcionando ao trabalhador sua inserção na vida em sociedade em pleno gozo de seus direitos fundamentais, desfrute de maior tempo de convívio em família, e sobretudo, em respeito aos princípios basilares da dignidade humana e do valor social do trabalho.

\section{Conclusões}

Atualmente predomina o entendimento de que ao impor limite de jornada ao trabalhador e fixar intervalos mínimos, o legislador visou tão somente a proteção do direito fundamental à saúde.

Contudo, paulatinamente a ordem jurídica tem se certificado de que o excesso de jornada, mormente, quando ocorrida de maneira habitual, obstrui não só a saúde do 
trabalhador, mas, outrossim, seu direito ao lazer, ao tempo livre, a liberdade criativa, ao convívio familiar e, consequentemente, ao pleno respeito a uma vida digna.

O trabalhador é essencial à atividade da empresa, cabendo ao Estado primar pela inviolabilidade de seus valores e bens fundamentais, visto que a Constituiçáo permite a distribuição de rendas e a sociabilização dos indivíduos, notando-se a prevalência do exercício ao lazer.

De tal modo, a exigência constante de jornada excessiva na busca de uma maior produtividade e lucratividade, configura-se como ato ilícito do empregador, o qual extrapola os limites do poder diretivo e disciplinar atingindo a esfera dos bens extrapatrimoniais do trabalhador, violando seus direitos existenciais, sobretudo, o direito ao lazer que é a vértice motora do exercício dos demais direitos, como a liberdade, o convívio familiar, a saúde (física e mental), a vida e demais direitos humanos.

Observa-se, pois, que a responsabilidade do empregador deve ser auxiliada com o Estado, através de uma maior fiscalização e sançóes mais efetivas aos empregadores que expuserem seus empregados às jornadas excessivas em demasia e verificarem se o respeito dos direitos fundamentais desses trabalhadores está sendo observado de forma equitativa.

Insta salientar que o exercício da cidadania não se restringe à antiga concepção dos direitos políticos, denota-se de maneira mais ampla, garantindo-se também, o livre exercício de todos os direitos civis e sociais, como o lazer.

Ademais, a garantia ao direito ao lazer do trabalhador, possui o arcabouço do princípio fundamental da cidadania, e dos princípios basilares da dignidade humana e do valor social do trabalho, que visam garantir os objetivos insculpidos na Constituição Federal.

Neste aspecto, muito embora seja estabelecido que a ordem econômica tenha como mote o desenvolvimento social do trabalho e a livre iniciativa, jamais desvia o foco da valorização dos direitos fundamentais do trabalhador, notadamente, dos direitos sociais como o lazer.

Com efeito, a empresa valorizada na sociedade não pode primar somente pela questão econômica do lucro, e sim, ater-se ao comportamento ético, e ao tratamento igualitário e com primor à dignidade de seus trabalhadores, em todos os bens intrínsecos e fundamentais ao ser, com plena garantia de todos seus direitos, almejando assim, a consolidaçáo de sua função social, a qual propicia o cumprimento dos objetivos constitucionais de criar uma sociedade livre, justa(igualitária) e solidária (fraterna).

\section{Referências}

BARROS, Alice Monteiro. Curso de Direito do Trabalho. São Paulo: Ltr, 2005.

BOBBIO, Norberto, A Era dos Direitos. SP: Editora campus, 2004. 
BONAVIDES, Paulo. Curso de Direito Constitucional. Editora Malheiros, 2002.

CALVET, Otavio Amaral. Direito ao lazer nas Relaçôes de Trabalho. São Paulo: LTR, 2006.

DALLEGRAVE NETO, José Affonso. Responsabilidade Civil no Direito do Trabalho. SP: LTr, 2009.

DELGADO, Maurício Godinho. Curso de Direito do Trabalho. LTr, 2008.

DUMAZEDIER, Joffre. Lazer e cultura popular. São Paulo: Perspectiva, 1976.

FIORELLI, José Osmir; MALHADAS JR, Marco Julio Olivé. Psicologia nas Relaçóes de Trabalho.São Paulo: LTr, 2003, pág 266.

GAGLIANO, Pablo Stolze; PAMPLONA FILHO, Rodolfo. Novo curso de Direito Civil. Contratos. São Paulo: Saraiva, 2005.

MAIOR, Jorge Luiz Souto. Do Direito à Desconexão do Trabalho. Revista do Tribunal Regional do Trabalho da 15a Região Disponível em: http://www.portal.trt15.jus.br/ biblioteca/revista23 acessado em 14/05/2015.

MARTINS, Sergio Pinto. Direitos Fundamentais Trabalhistas. São Paulo: Atlas, 2009.

MIRANDA, Jorge. Manual de Direito Constitucional. São Paulo: Método, 1998.

NASCIMENTO, Amauri Mascaro. Curso do Direito do Trabalho, São Paulo: Saraiva, 2009.

NIETZSCHE, F. Humano Demasiado Humano. Trad. Paulo César de Souza. São Paulo: Companhia das Letras, 2000, p. 37.

PIOVESAN, Flávia. Direitos Humanos e o Direito Constitucional Internacional, rev.ampliada e atualizada. São Paulo:Saraiva, 2010.

REQUIXA, Renato. O lazer no Brasil. São Paulo: Brasiliense, 1977, p.51.

RUFINO, Regina Célia Pezzuto. Assédio Moral no Âmbito da Empresa, SP: LTr, 2011.

SARLET, Ingo Wolfgang. Dignidade da pessoa humana e direitos fundamentais na Constituição Federal de 1988. Porto Alegre: Livraria do Advogado, 200, p.37.

VALE, André Rufino. Constituição e Direito Privado. Algumas Consideraçóes sobre a Eficácia dos Direitos Fundamentais nas Relaçóes Privadas. Revista do Direito Público n. 06 - out., nov. e dez/2004, p.32.

\section{Webgrafia Geral}

OIT. Site oficial. Disponível em: <http://www.oitbrasil.org.br>. Acesso em: 21 Abr. 2015. TRIBUNAL SUPERIOR DO TRABALHO. Site oficial. Disponível em: <http:// www. tst.gov.br>. Acesso em: 21 Abr. 2015. 
TRIBUNAL SUPERIOR DO TRABALHO. Site oficial. Disponível em: <http:// www. tst.gov.br>. Acesso em: 21 Abr. 2015.

CONJUR. Site oficial: http://www.conjur.com.br/2015-mai-12/magazine-luiza-condenado-100-mil-jornada-excessiva, acessado em 13/05/2015. 